\title{
Bacillus nanhaiisediminis sp. nov., an alkalitolerant member of Bacillus rRNA group 6
}

\author{
Jianli Zhang, ${ }^{1}$ Jiewei Wang, ${ }^{1}$ Fei Song, ${ }^{1}$ Caiyuan Fang, ${ }^{1}$ Yuhua $\mathrm{Xin}^{2}$ \\ and Yabo Zhang ${ }^{1}$ \\ ${ }^{1}$ School of Life Science, Beijing Institute of Technology, Beijing 100081, PR China \\ ${ }^{2}$ China General Microbiological Culture Collection Center, Institute of Microbiology, Chinese \\ Academy of Sciences, Beijing 100101, PR China
}

Correspondence

Jianli Zhang

zhangjianli@bit.edu.cn
During the past decade, studies on the ecology, physiology and taxonomy of alkaliphilic and alkalitolerant microbes have revealed an impressive diversity. Since Vedder (1934) first isolated the aerobic, endospore-forming, obligately alkaliphilic bacterium Bacillus alcalophilus, many obligately or facultatively alkaliphilic Bacillus strains have been isolated in order to investigate their physiological adaptation to high $\mathrm{pH}$ and to utilize their enzymes industrially (Horikoshi, 1971, 1999; Yamamoto et al., 1972; Hayashi et al., 1988). Nielsen et al. (1994) established a new rRNA group, designated rRNA group 6, that contains some alkaliphilic and alkalitolerant bacilli. Bacillus species that belong to rRNA group 6 have been found to form a phylogenetic clade that is distinct from other related genera, as well as Bacillus rRNA group 1, which includes Bacillus subtilis, the type species of the genus (Nielsen et al., 1994; Schlesner et al., 2001). At the time of writing, more than 20 alkaliphilic Bacillus species have been identified (Vedder, 1934; Spanka \& Fritze, 1993; Nielsen et al., 1995;

The GenBank/EMBL/DDBJ accession number for the 16S rRNA gene sequence of strain $\mathrm{NH}^{\top}{ }^{\top}$ is GQ292773.

Two supplementary figures and a supplementary table are available with the online version of this paper.
Agnew et al., 1995; Fritze, 1996; Switzer Blum et al., 1998; Yumoto et al., 1998, 2003; Li et al., 2002; Olivera et al., 2005; Nowlan et al., 2006; Borchert et al., 2007). A sampling campaign during an ecological survey of sea-mud bacteria in the South China Sea led to the isolation of a pale-yellow-pigmented bacterium, designated strain $\mathrm{NH}^{\mathrm{T}}$. The aim of the present study was to determine the exact taxonomic status of strain $\mathrm{NH}^{\mathrm{T}}$ by using a polyphasic approach. Phenotypic and chemotaxonomic characteristics and phylogenetic analysis based on 16S rRNA gene sequences showed that the new isolate merited classification as the type strain of a novel Bacillus species.

Strain $\mathrm{NH}^{\mathrm{T}}$ was isolated on marine agar 2216 (MA; Difco), which had been seeded with a sea-mud suspension and incubated at $37{ }^{\circ} \mathrm{C}$ for 3 days. The sediment sample was collected at a depth of $900 \mathrm{~m}$. Strain $\mathrm{NH}^{\mathrm{T}}$ was maintained on Luria-Bertani (LB) agar (per litre distilled water: $10 \mathrm{~g}$ tryptone, $5 \mathrm{~g}$ yeast extract and $10 \mathrm{~g} \mathrm{NaCl}$; $\mathrm{pH} 9.0)$ at $4{ }^{\circ} \mathrm{C}$ and as glycerol suspensions $(20 \%$, v/v) at $-20{ }^{\circ} \mathrm{C}$. Cell biomass of strain $\mathrm{NH} 3^{\mathrm{T}}$ for most of the chemotaxonomic and molecular-systematic studies was prepared as described by Zhang et al. (2002), with the modification that the strain was grown in shake flasks of LB broth. 
Micromorphological and colonial properties were examined on LB agar, nutrient agar and MA for $36-48 \mathrm{~h}$ at $37^{\circ} \mathrm{C}$. Cellular morphology was examined by light microscopy (BH-2; Olympus). Gram staining was performed as described by Gerhardt et al. (1981). The presence of flagella and spores was assessed according to the methods of Das et al. (1996) and Kanso \& Patel (2003). Cells of strain $\mathrm{NH}^{\mathrm{T}}{ }^{\mathrm{w}}$ were motile and Gram-stain-positive. Cells were rod-shaped $(0.5-0.7 \times 1.3-2.5 \mu \mathrm{m})$ with round ends. Spores were observed from cultures grown under different conditions (Supplementary Fig. S1, available in IJSEM Online). Cultures were resistant to heat $\left(70-100{ }^{\circ} \mathrm{C}\right.$ for $10 \mathrm{~min}$ ), supporting the notion that strain $\mathrm{NH}^{\mathrm{T}}$ was a spore-former. Colonies were smooth, circular to slightly irregular, slightly raised, pale yellow and $0.5-2.0 \mathrm{~mm}$ in diameter after $36-48 \mathrm{~h}$ of cultivation at $37^{\circ} \mathrm{C}$ on $\mathrm{LB}$ agar.

Strain $N H 3^{\mathrm{T}}$ was examined for a range of phenotypic properties. Utilization of sole carbon sources from carbohydrates was assessed according to the procedures described by Gordon et al. $(1974,1977)$ and Zhang et al. (2009). Catalase activity was determined on freshly growing colonies by using $3 \%(\mathrm{v} / \mathrm{v})$ hydrogen peroxide solution. Hydrolysis reactions and determination of oxidative or fermentative catabolism were carried out according to Smibert \& Krieg (1994) and La Scola et al. (2003). Growth under various $\mathrm{pH}$, temperature and $\mathrm{NaCl}$ regimes was determined on LB agar plates incubated for up to 5 days. Anaerobic growth was tested in TYEG medium (Wynter et al., 1996). Resistance to lysozyme was determined by the method of Gordon et al. (1973). Resistance to antibiotics was examined by placing impregnated filter-paper discs (Goodfellow \& Orchard, 1974) on LB agar; the results were recorded following incubation at $37^{\circ} \mathrm{C}$ for up to 3 days. Strain $\mathrm{NH} 3^{\mathrm{T}}$ grew optimally at $37{ }^{\circ} \mathrm{C}$ (range $10-43{ }^{\circ} \mathrm{C}$ ) and did not grow in the presence of more than $11 \%(\mathrm{w} / \mathrm{v}) \mathrm{NaCl}$. Growth was observed at $\mathrm{pH} 6.5-10$ but not at $\mathrm{pH} \mathrm{6}$, and the optimum $\mathrm{pH}$ for growth $(\mathrm{pH} 9)$ confirmed strain $\mathrm{NH}^{\mathrm{T}}$ to be an alkalitolerant bacterium. The organism did not grow anaerobically in TYEG medium. Strain $\mathrm{NH}^{\mathrm{T}}$ was catalase-positive but oxidase-negative. A range of carbohydrates were used as sole carbon sources. The phenotypic properties of strain $\mathrm{NH} 3^{\mathrm{T}}$ are summarized in the species description and compared with those of related species of the genus Bacillus in detail in Table 1.

Peptidoglycan was prepared and analysed according to the method described by Komagata \& Suzuki (1987). Isoprenoid quinones were extracted and purified according to Collins et al. (1987); purified menaquinones were identified by reversed-phase HPLC (Wu et al., 1989). For quantitative analysis of cellular fatty acids, cell mass was harvested and fatty acids were extracted, purified, methylated and identified by using the standard Microbial Identification System (MIDI) (Sasser, 1990; Kämpfer \& Kroppenstedt, 1996). Polar lipids were extracted from freeze-dried cell material and separated by two-dimensional silica-gel TLC as described by Tindall (1990). Chromatographs of the polar lipids were stained with ninhydrin, molybdenum blue and $\alpha$-naphthol. The $\mathrm{G}+\mathrm{C}$ content of the DNA was determined by means of the thermal denaturation method (Marmur \& Doty, 1962) with DNA from Escherichia coli AS 1.365 as a reference. Strain $\mathrm{NH} 3^{\mathrm{T}}$ contained meso-diaminopimelic acid as the diagnostic diamino acid in the cell-wall peptidoglycan. The predominant isoprenoid quinone was unsaturated menaquinone with seven isoprene units (MK-7). Strain $\mathrm{NH}^{\mathrm{T}}$ contained iso- $\mathrm{C}_{15: 0}$, iso- $\mathrm{C}_{14: 0}$ and iso- $\mathrm{C}_{16: 0}$ as the major fatty acids (see Supplementary Table S1 for detailed results); these branched compounds are typical of the fatty acids found in the cell membranes of Bacillus species (Kämpfer, 1994; Albert et al., 2005). The major polar lipids of strain $\mathrm{NH}^{\mathrm{T}}$ were phosphatidylethanolamine, phosphatidylglycerol and diphosphatidylglycerol. Minor amounts of one unknown aminophospholipid and one glycolipid were found (Supplementary Fig. S2). These chemotaxonomic features of strain $\mathrm{NH}^{\mathrm{T}}$ were typical of those found in members of the genus Bacillus (Priest et al., 1988; Heyrman et al., 2004; Albert et al., 2005, 2007; Wieser et al., 2005; Lim et al., 2006a, b; Xue et al., 2008). The DNA G + C content of strain $\mathrm{NH}^{\mathrm{T}}$ was $40.3 \mathrm{~mol} \%$, a value that falls within the range defined for the genus Bacillus (Nielsen et al., 1995; Priest et al., 1988).

Preparation of genomic DNA, PCR-mediated amplification of the 16S rRNA gene and purification of the PCR product from strain $\mathrm{NH} 3^{\mathrm{T}}$ were carried out according to Rainey et al. (1996). The PCR product was sequenced directly by using the method of Lu et al. (2001). Sequence gel electrophoresis was performed; the nucleotide sequences were obtained automatically by using an Applied Biosystems DNA sequencer (model 377) and software provided by the manufacturer. Identification of phylogenetic neighbours and calculation of levels of pairwise 16S rRNA gene sequence similarity were achieved by using the EzTaxon server 2.1 (http://www.eztaxon.org/; Chun et al., 2007). Multiple alignment with sequences from closely related species was performed by using CLUSTAL x 1.8 (Thompson et al., 1997). Phylogenetic trees were reconstructed with the neighbour-joining (Saitou \& Nei, 1987) and maximum-parsimony (Kluge \& Farris, 1969) algorithms in MEGA version 4 (Tamura et al., 2007). A maximum-likelihood (Felsenstein, 1981) tree was generated by using the treeing algorithms contained in the PHYLIP package (Felsenstein, 2004). Evolutionary distance matrices were generated according to Kimura (1980). Topologies of the resultant unrooted trees were evaluated by bootstrap analyses (Felsenstein, 1985) of the neighbour-joining dataset, based on 1000 resamplings. An almost-complete $16 \mathrm{~S}$ rRNA gene sequence was obtained for strain $\mathrm{NH}^{\mathrm{T}}$ (1419 nt). 16S rRNA gene sequence analysis showed that strain $\mathrm{NH} 3^{\mathrm{T}}$ was related phylogenetically to members of the family Bacillaceae and belonged within the phyletic group classically defined as the genus Bacillus, particularly Bacillus species that have been designated as belonging to rRNA group 6 . In the neighbour-joining phylogenetic tree, it was apparent that strain $\mathrm{NH}^{\mathrm{T}}$ formed a distinct phyletic line 
Table 1. Phenotypic characteristics that differentiate strain $\mathrm{NH}^{\top}$ from the type strains of phylogenetically related Bacillus species

Strains: 1, NH3 ${ }^{\mathrm{T}}$; 2, B. akibai JCM $9157^{\mathrm{T}}$; 3, B. alkalidiazotrophicus $\mathrm{NCCB} 100213^{\mathrm{T}}$; 4, B. okhensis JCM 13040 ${ }^{\mathrm{T}}$; , B. pseudofirmus DSM 8715 ${ }^{\mathrm{T}}$. All strains are rod-shaped and positive for utilization of D-glucose and D-mannose. Data were obtained in this study unless indicated otherwise. + , Positive; -, negative; w, weakly positive; v, variable.

\begin{tabular}{|c|c|c|c|c|c|}
\hline Characteristic & 1 & 2 & 3 & 4 & 5 \\
\hline Cell width $(\mu \mathrm{m})$ & $0.5-0.7$ & $0.6-0.8$ & $0.6-1.2$ & $0.6-0.8$ & $0.6-0.8$ \\
\hline Cell length $(\mu \mathrm{m})$ & $1.3-2.5$ & $3.0-4.0$ & $3.0-8.0$ & $2.0-2.9$ & $3.0-6.0$ \\
\hline Colony margin & Slightly irregular & Entire & Irregular & Irregular & Irregular \\
\hline Spore formation & + & + & + & - & + \\
\hline \multicolumn{6}{|l|}{ Ranges for growth } \\
\hline $\mathrm{NaCl}(\%, \mathrm{w} / \mathrm{v})$ & $0-11$ & $0-7$ & $0.5-7$ & $0-10$ & $0-16$ \\
\hline $\mathrm{pH}$ & $6.5-10$ & $8-10$ & $7.8-10.6$ & $7-10$ & $8-10$ \\
\hline pH optimum & 9 & $9-10$ & 9.5 & 9 & 9 \\
\hline Nitrate reduction & + & + & - & - & - \\
\hline \multicolumn{6}{|l|}{ Hydrolysis of: } \\
\hline Casein & - & - & - & + & + \\
\hline myo-Inositol & - & - & - & - & $\mathrm{w}$ \\
\hline Lactose & - & - & $\mathrm{W}$ & + & - \\
\hline D-Mannitol & + & + & + & - & $\mathrm{V}$ \\
\hline Melezitose & + & + & + & - & - \\
\hline Melibiose & + & - & + & - & - \\
\hline Raffinose & + & - & + & - & - \\
\hline$\alpha$-L-Rhamnose & + & - & - & + & - \\
\hline D-Ribose & - & - & - & + & + \\
\hline D-Sorbitol & + & + & - & - & - \\
\hline Sucrose & - & + & + & - & + \\
\hline Trehalose & + & + & + & - & + \\
\hline
\end{tabular}

${ }^{\star}$ Data taken from: $a$, Nogi et al. (2005); b, Sorokin et al. (2008); c, Nowlan et al. (2006); $d$, Nielsen et al. (1995) (range of values for 23 strains, including the type strain).

within the Bacillus rRNA group 6 clade (Fig. 1). Strain $\mathrm{NH}^{\mathrm{T}}$ was related most closely to Bacillus akibai $1139^{\mathrm{T}}$ (96.82\% 16S rRNA gene sequence similarity), B. pseudofirmus DSM $8715^{\mathrm{T}}(96.76 \%)$, B. okhensis Kh10-101 ${ }^{\mathrm{T}}$ $(96.76 \%)$ and B. alkalidiazotrophicus MS $6^{\mathrm{T}}(96.47 \%)$. DNA-DNA hybridization experiments between strain $\mathrm{NH}^{\mathrm{T}}$ and its nearest phylogenetic neighbours were not performed because strains with $16 \mathrm{~S}$ rRNA gene sequences that differ by more than $3 \%$ are unlikely to exhibit more than $70 \%$ relatedness at the whole-genome level (Stackebrandt \& Goebel, 1994; Stackebrandt et al., 2002; Stackebrandt \& Ebers, 2006).

A range of phenotypic properties distinguished strain $\mathrm{NH} 3^{\mathrm{T}}$ from its closest phylogenetic neighbours (Table 1 ). In particular, B. akibai JCM $9157^{\mathrm{T}}$ grew at $20-45{ }^{\circ} \mathrm{C}$, tolerated $7 \% \mathrm{NaCl}$, hydrolysed starch and utilized
D-fructose, sucrose and D-xylose as sole carbon sources, but not melibiose, raffinose or $\alpha$-L-rhamnose; $B$. pseudofirmus DSM $8715^{\mathrm{T}}$ grew at $10-45{ }^{\circ} \mathrm{C}$, tolerated $16 \% \mathrm{NaCl}$, hydrolysed casein, gelatin and starch, utilized D-fructose, myo-inositol (weakly), D-ribose, sucrose and D-xylose as sole carbon sources, but not $\alpha$-L-rhamnose or D-sorbitol, and did not reduce nitrate; B. okhensis JCM $13040^{\mathrm{T}}$ grew at $25-40{ }^{\circ} \mathrm{C}$, tolerated $10 \% \mathrm{NaCl}$, hydrolysed casein, gelatin and starch, utilized D-fructose, lactose, D-ribose and Dxylose as sole carbon sources and did not reduce nitrate; $B$. alkalidiazotrophicus NCCB $100213^{\mathrm{T}}$ grew at $15-43{ }^{\circ} \mathrm{C}$, tolerated $7 \% \mathrm{NaCl}$, hydrolysed starch, utilized D-fructose, lactose (weakly) and sucrose as sole carbon sources, but not $\alpha$-L-rhamnose or D-sorbitol, and did not reduce nitrate; strain $\mathrm{NH} 3{ }^{\mathrm{T}}$ grew at $10-43{ }^{\circ} \mathrm{C}$, tolerated $11 \%(\mathrm{w} / \mathrm{v}) \mathrm{NaCl}$, did not hydrolyse casein, gelatin or starch, utilized $\alpha$-Lrhamnose and D-sorbitol as sole carbon sources, but not 


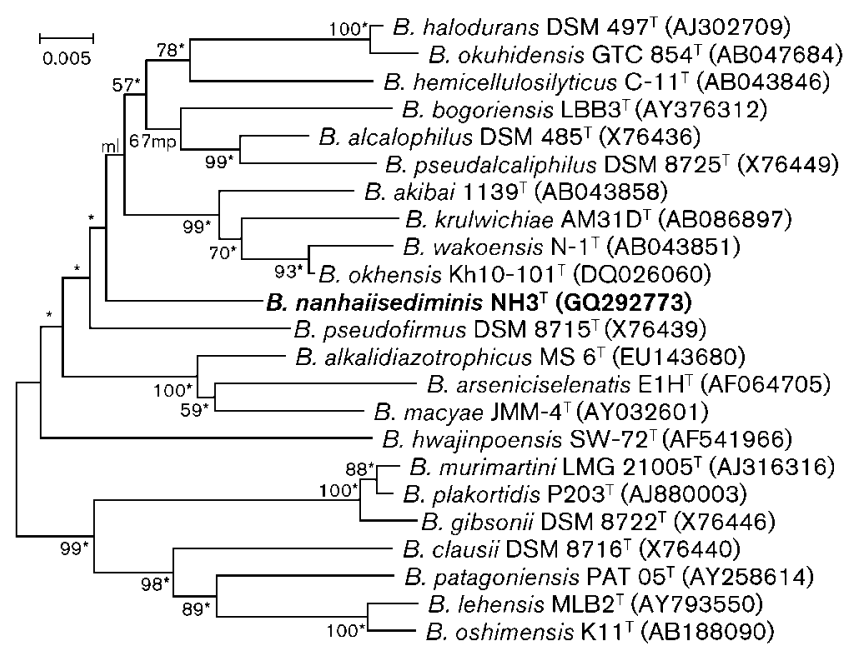

Fig. 1. Phylogenetic tree showing the relationships between strain $\mathrm{NH}^{\top}{ }^{\top}$ and the type strains of closely related Bacillus species, constructed by using the neighbour-joining method and based on nearly complete $16 \mathrm{~S}$ rRNA gene sequences. Asterisks indicate branches of the tree that were also recovered by using both the maximum-parsimony and the maximum-likelihood tree-making algorithms; 'mp' and 'ml' denote branches of the tree that were also recovered by using the maximum-parsimony or maximumlikelihood method, respectively. Numbers at nodes indicate percentage levels of bootstrap support based on a neighbourjoining analysis of 1000 resampled datasets; only values $>50 \%$ are given. Bar, 0.005 substitutions per site.

D-fructose, myo-inositol, D-ribose, sucrose or D-xylose, and reduced nitrate.

On the basis of the data presented, we conclude that strain $\mathrm{NH} 3^{\mathrm{T}}$ merits recognition as the type strain of a novel species of the genus Bacillus, for which the name Bacillus nanhaiisediminis sp. nov. is proposed.

\section{Description of Bacillus nanhaiisediminis sp. nov.}

Bacillus nanhaiisediminis (nan.hai.i.se.di'mi.nis. N.L. n. nanhaium Nan Hai, the Chinese name for the South China Sea; L. n. sedimen -inis a sediment; N.L. gen. n. nanhaiisediminis of a sediment from the South China Sea).

Cells are Gram-stain-positive, aerobic rods, 0.5-0.7 $\mu \mathrm{m}$ wide and 1.3-2.5 $\mu \mathrm{m}$ long. Cells are motile by means of peritrichous flagella. Ellipsoidal endospores are formed subterminally or centrally. Colonies are pale yellow, convex, smooth, circular to slightly irregular and 0.5$2.0 \mathrm{~mm}$ in diameter after $36-48 \mathrm{~h}$ at $37^{\circ} \mathrm{C}$ on LB agar. Grows well on nutrient agar. Diffusible pigments are not formed. Positive for catalase and phenylalanine dehydrogenase. Negative in assays for oxidase, egg-yolk reaction, arginine dihydrolase, lipase and ONPG hydrolysis. Grows at $10-43{ }^{\circ} \mathrm{C}$ (optimum $37{ }^{\circ} \mathrm{C}$ ) and at $\mathrm{pH}$ 6.5-10.0 (optimum $\mathrm{pH}$ 9.0). Hydrolyses urea but not gelatin, casein, starch, aesculin, arbutin, tyrosine, adenine, guanine, xanthine or hypoxanthine. Nitrate is reduced. Indole reaction is positive, but methyl red and Voges-Proskauer reactions are negative. Hydrogen sulfide is not produced. Utilizes L-arabinose, cellobiose, D-galactose, glucosamine hydrochloride, D-glucose, 3-methyl glucose, glycerol, maltose, D-mannitol, D-mannose, melezitose, melibiose, raffinose, $\alpha$-L-rhamnose, D-sorbitol, trehalose, D-xylitol, acetate, fumaric acid, pyruvic acid, sorbic acid and succinate as sole carbon and energy sources, but not aesculin, arbutin, meso-erythritol, D-fructose, $\mathrm{N}$-acetyl-Dglucosamine, glycogen, myo-inositol, lactose, D-ribose, L-sorbose, sucrose, D-xylose, benzoin, citrate, creatine, lactic acid, oxalate or tartrate. Growth occurs in the presence of $0-11 \%(\mathrm{w} / \mathrm{v}) \mathrm{NaCl}$ but not $12 \%$. Resistant to ( $\mu \mathrm{g}$ per disc unless otherwise stated) aztreonam (30) and streptomycin sulphate (10), but susceptible to amikacin (30), amoxicillin plus clavulanic acid (10), ampicillin (10), cefotaxime (30), chloramphenicol (30), ciprofloxacin (5), clindamycin hydrochloride (2), erythromycin (15), gentamicin sulphate (10), kanamycin sulphate (30), mezlocillin (75), ofloxacin (5), penicillin $\mathrm{G}$ (10 IU), rifampicin (5), tetracycline hydrochloride (30), tobramycin sulphate (10) and lysozyme $(0.005 \%, \mathrm{w} / \mathrm{v})$. The cell-wall peptidoglycan contains meso-diaminopimelic acid. MK-7 is the major menaquinone. The main fatty acids are iso- $\mathrm{C}_{15: 0}$, iso$\mathrm{C}_{14: 0}$, iso- $\mathrm{C}_{16: 0}$, anteiso- $\mathrm{C}_{15: 0}, \mathrm{C}_{16: 1} \omega 7 c$ alcohol, $\mathrm{C}_{16: 0}$, $\mathrm{C}_{16: 1} \omega 11 c$ and iso- $\mathrm{C}_{17: 0}$. The polar lipids are phosphatidylethanolamine, phosphatidylglycerol and diphosphatidylglycerol, and minor amounts of one unknown aminophospholipid and one glycolipid. The DNA G $+\mathrm{C}$ content of the type strain is $40.3 \mathrm{~mol} \%$.

The type strain, $\mathrm{NH}^{\mathrm{T}}$ (=CGMCC $1.10116^{\mathrm{T}}=\mathrm{JCM}$ $\left.16507^{\mathrm{T}}\right)$, was isolated from a sediment sample collected from the South China Sea.

\section{Acknowledgements}

This research was supported by the National Natural Science Foundation of China (NSFC) (grant no. 30970009), the Special Fund for Public Welfare Industrial (Agriculture) Research of China (grant no. 200903001) and the Basic Research Foundation of Beijing Institute of Technology (grant nos 20081642008 and 20091642006). We are grateful to Dr Yafang Tan for carrying out quantitative fatty acid analysis on strain $\mathrm{NH}^{\mathrm{T}}$.

\section{References}

Agnew, M. D., Koval, S. F. \& Jarrell, K. F. (1995). Isolation and characterization of novel alkaliphiles from bauxite-processing waste and description of Bacillus vedderi sp. nov., a new obligate alkaliphile. Syst Appl Microbiol 18, 221-230.

Albert, R. A., Archambault, J., Rosselló-Mora, R., Tindall, B. J. \& Matheny, M. (2005). Bacillus acidicola sp. nov., a novel mesophilic, acidophilic species isolated from acidic Sphagnum peat bogs in Wisconsin. Int J Syst Evol Microbiol 55, 2125-2130.

Albert, R. A., Archambault, J., Lempa, M., Hurst, B., Richardson, C., Gruenloh, S., Duran, M., Worliczek, H. L., Huber, B. E. \& other authors (2007). Proposal of Viridibacillus gen. nov. and reclassification of Bacillus arvi, Bacillus arenosi and Bacillus neidei as Viridibacillus arvi 
gen. nov., comb. nov., Viridibacillus arenosi comb. nov. and Viridibacillus neidei comb. nov. Int J Syst Evol Microbiol 57, 2729-2737.

Borchert, M. S., Nielsen, P., Graeber, I., Kaesler, I., Szewzyk, U., Pape, T., Antranikian, G. \& Schäfer, T. (2007). Bacillus plakortidis sp. nov. and Bacillus murimartini sp. nov., novel alkalitolerant members of rRNA group 6. Int J Syst Evol Microbiol 57, 2888-2893.

Chun, J., Lee, J.-H., Jung, Y., Kim, M., Kim, S., Kim, B. K. \& Lim, Y. W. (2007). EzTaxon: a web-based tool for the identification of prokaryotes based on $16 \mathrm{~S}$ ribosomal RNA gene sequences. Int J Syst Evol Microbiol 57, 2259-2261.

Collins, M. D., Howarth, O. W., Grund, E. \& Kroppenstedt, R. M. (1987). Isolation and structural determination of new members of the vitamin $\mathrm{K}_{2}$ series in Nocardia brasiliensis. FEMS Microbiol Lett 41, 3539.

Das, S. K., Mishra, A. K., Tindall, B. J., Rainey, F. A. \& Stackebrandt, E. (1996). Oxidation of thiosulfate by a new bacterium, Bosea thiooxidans (strain BI-42) gen. nov., sp. nov.: analysis of phylogeny based on chemotaxonomy and $16 \mathrm{~S}$ ribosomal DNA sequencing. Int $J$ Syst Bacteriol 46, 981-987.

Felsenstein, J. (1981). Evolutionary trees from DNA sequences: a maximum likelihood approach. J Mol Evol 17, 368-376.

Felsenstein, J. (1985). Confidence limits on phylogenies: an approach using the bootstrap. Evolution 39, 783-791.

Felsenstein, J. (2004). PHYLIP (phylogeny inference package) version 3.6. Distributed by the author. Department of Genome Sciences, University of Washington, Seattle, USA.

Fritze, D. (1996). Bacillus haloalkaliphilus sp. nov. Int J Syst Bacteriol 46, 98-101.

Gerhardt, P., Murray, R. G. E., Costilow, R. N., Nester, E. W., Wood, W. A., Krieg, N. R. \& Phillips, G. B. (editors) (1981). Manual of Methods for General Bacteriology. Washington, DC: American Society for Microbiology.

Goodfellow, M. \& Orchard, V. A. (1974). Antibiotic sensitivity of some nocardioform bacteria and its value as a criterion for taxonomy. J Gen Microbiol 83, 375-387.

Gordon, R. E., Haynes, W. C. \& Pang, C. H.-N. (1973). The genus Bacillus. Agriculture Handbook no. 427. Washington, DC: US Department of Agriculture.

Gordon, R. E., Barnett, D. A., Handerhan, J. E. \& Pang, C. H.-N. (1974). Nocardia coeliaca, Nocardia autotrophica, and the nocardin strain. Int J Syst Bacteriol 24, 54-63.

Gordon, R. E., Hyde, J. L. \& Moore, J. A., Jr (1977). Bacillus firmusBacillus lentus: a series or one species? Int J Syst Bacteriol 27, 256-262.

Hayashi, T., Akiba, T. \& Horikoshi, K. (1988). Production and purification of new maltohexaose-forming amylases from alkalophilic Bacillus sp. H-167. Agric Biol Chem 52, 443-448.

Heyrman, J., Vanparys, B., Logan, N. A., Balcaen, A., Rodríguez-Díaz, M., Felske, A. \& De Vos, P. (2004). Bacillus novalis sp. nov., Bacillus vireti sp. nov., Bacillus soli sp. nov., Bacillus bataviensis sp. nov. and Bacillus drentensis sp. nov., from the Drentse A grasslands. Int J Syst Evol Microbiol 54, 47-57.

Horikoshi, K. (1971). Production of alkaline enzymes by alkalophilic microorganisms. Part I. Alkaline protease produced by Bacillus no. 221. Agric Biol Chem 36, 1407-1414.

Horikoshi, K. (1999). Alkaliphiles. Tokyo: Kodansha.

Kämpfer, P. (1994). Limits and possibilities of total fatty acid analysis for classification and identification of Bacillus species. Syst Appl Microbiol 17, 86-98.

Kämpfer, P. \& Kroppenstedt, R. M. (1996). Numerical analysis of fatty acid patterns of coryneform bacteria and related taxa. Can $J$ Microbiol 42, 989-1005.
Kanso, S. \& Patel, B. K. C. (2003). Microvirga subterranea gen. nov., sp. nov., a moderate thermophile from a deep subsurface Australian thermal aquifer. Int J Syst Evol Microbiol 53, 401-406.

Kimura, M. (1980). A simple method for estimating evolutionary rates of base substitutions through comparative studies of nucleotide sequences. J Mol Evol 16, 111-120.

Kluge, A. G. \& Farris, F. S. (1969). Quantitative phyletics and the evolution of anurans. Syst Zool 18, 1-32.

Komagata, K. \& Suzuki, K. (1987). Lipid and cell wall analysis in bacterial systematics. Methods Microbiol 19, 161-207.

La Scola, B., Mallet, M. N., Grimont, P. A. D. \& Raoult, D. (2003). Bosea eneae sp. nov., Bosea massiliensis sp. nov. and Bosea vestrisii sp. nov., isolated from hospital water supplies, and emendation of the genus Bosea (Das et al. 1996). Int J Syst Evol Microbiol 53, 15-20.

Li, Z., Kawamura, Y., Shida, O., Yamagata, S., Deguchi, T. \& Ezaki, T. (2002). Bacillus okuhidensis sp. nov., isolated from the Okuhida spa area of Japan. Int J Syst Evol Microbiol 52, 1205-1209.

Lim, J.-M., Jeon, C. O., Lee, S.-M., Lee, J.-C., Xu, L.-H., Jiang, C.-L. \& Kim, C.-J. (2006a). Bacillus salarius sp. nov., a halophilic, sporeforming bacterium isolated from a salt lake in China. Int J Syst Evol Microbiol 56, 373-377.

Lim, J.-M., Jeon, C. O. \& Kim, C.-J. (2006b). Bacillus taeanensis sp. nov., a halophilic Gram-positive bacterium from a solar saltern in Korea. Int J Syst Evol Microbiol 56, 2903-2908.

Lu, Z., Liu, Z., Wang, L., Zhang, Y., Qi, W. \& Goodfellow, M. (2001). Saccharopolyspora flava sp. nov. and Saccharopolyspora thermophila sp. nov., novel actinomycetes from soil. Int J Syst Evol Microbiol 51, 319-325.

Marmur, J. \& Doty, P. (1962). Determination of the base composition of deoxyribonucleic acid from its thermal denaturation temperature. J Mol Biol 5, 109-118.

Nielsen, P., Rainey, F. A., Outtrup, H., Priest, F. G. \& Fritze, D. (1994). Comparative $16 \mathrm{~S}$ rDNA sequence analysis of some alkaliphilic bacilli and the establishment of a sixth rRNA group within the genus Bacillus. FEMS Microbiol Lett 117, 61-65.

Nielsen, P., Fritze, D. \& Priest, F. G. (1995). Phenetic diversity of alkaliphilic Bacillus strains: proposal for nine new species. Microbiology 141, 1745-1761.

Nogi, Y., Takami, H. \& Horikoshi, K. (2005). Characterization of alkaliphilic Bacillus strains used in industry: proposal of five novel species. Int J Syst Evol Microbiol 55, 2309-2315.

Nowlan, B., Dodia, M. S., Singh, S. P. \& Patel, B. K. C. (2006). Bacillus okhensis sp. nov., a halotolerant and alkalitolerant bacterium from an Indian saltpan. Int J Syst Evol Microbiol 56, 1073-1077.

Olivera, N., Siñeriz, F. \& Breccia, J. D. (2005). Bacillus patagoniensis sp. nov., a novel alkalitolerant bacterium from the rhizosphere of Atriplex lampa in Patagonia, Argentina. Int J Syst Evol Microbiol 55, 443-447.

Priest, F. G., Goodfellow, M. \& Todd, C. (1988). A numerical classification of the genus Bacillus. J Gen Microbiol 134, 1847-1882.

Rainey, F. A., Ward-Rainey, N., Kroppenstedt, R. M. \& Stackebrandt, E. (1996). The genus Nocardiopsis represents a phylogenetically coherent taxon and a distinct actinomycete lineage: proposal of Nocardiopsaceae fam. nov. Int J Syst Bacteriol 46, 1088-1092.

Saitou, N. \& Nei, M. (1987). The neighbor-joining method: a new method for reconstructing phylogenetic trees. Mol Biol Evol 4, 406425.

Sasser, M. (1990). Identification of bacteria by gas chromatography of cellular fatty acids, Technical Note 101. Newark, DE: MIDI, Inc.

Schlesner, H., Lawson, P. A., Collins, M. D., Weiss, N., Wehmeyer, U., Völker, H. \& Thomm, M. (2001). Filobacillus milensis gen. nov., sp. 
nov., a new halophilic spore-forming bacterium with Orn-D-Glu-type peptidoglycan. Int J Syst Evol Microbiol 51, 425-431.

Smibert, R. M. \& Krieg, N. R. (1994). Phenotypic characterization. In Methods for General and Molecular Bacteriology, pp. 607-654. Edited by P. Gerhardt, R. G. E. Murray, W. A. Wood \& N. R. Krieg. Washington, DC: American Society for Microbiology.

Sorokin, I. D., Kravchenko, I. K., Tourova, T. P., Kolganova, T. V., Boulygina, E. S. \& Sorokin, D. Y. (2008). Bacillus alkalidiazotrophicus sp. nov., a diazotrophic, low salt-tolerant alkaliphile isolated from Mongolian soda soil. Int J Syst Evol Microbiol 58, 2459-2464.

Spanka, R. \& Fritze, D. (1993). Bacillus cohnii sp. nov., a new, obligately alkaliphilic, oval-spore-forming Bacillus species with ornithine and aspartic acid instead of diaminopimelic acid in the cell wall. Int J Syst Bacteriol 43, 150-156.

Stackebrandt, E. \& Ebers, J. (2006). Taxonomic parameters revisited: tarnished gold standards. Microbiol Today 33, 152-155.

Stackebrandt, E. \& Goebel, B. M. (1994). Taxonomic note: a place for DNA-DNA reassociation and $16 \mathrm{~S}$ rRNA sequence analysis in the present species definition in bacteriology. Int J Syst Bacteriol 44, 846849.

Stackebrandt, E., Frederiksen, W., Garrity, G. M., Grimont, P. A. D., Kämpfer, P., Maiden, M. C. J., Nesme, X., Rosselló-Mora, R., Swings, J. $\&$ other authors (2002). Report of the ad hoc committee for the reevaluation of the species definition in bacteriology. Int J Syst Evol Microbiol 52, 1043-1047.

Switzer Blum, J., Burns Bindi, A., Buzzelli, J., Stolz, J. F. \& Oremland, R. S. (1998). Bacillus arsenicoselenatis, sp. nov., and Bacillus selenitireducens, sp. nov.: two haloalkaliphiles from Mono Lake, California that respire oxyanions of selenium and arsenic. Arch Microbiol 171, 19-30.

Tamura, K., Dudley, J., Nei, M. \& Kumar, S. (2007). MEGA4: molecular evolutionary genetics analysis (MEGA) software version 4.0. Mol Biol Evol 24, 1596-1599.

Thompson, J. D., Gibson, T. J., Plewniak, F., Jeanmougin, F. \& Higgins, D. G. (1997). The CLUSTAL_X windows interface: flexible strategies for multiple sequence alignment aided by quality analysis tools. Nucleic Acids Res 25, 4876-4882.
Tindall, B. J. (1990). A comparative study of the lipid composition of Halobacterium saccharovorum from various sources. Syst Appl Microbiol 13, 128-130.

Vedder, A. (1934). Bacillus alcalophilus n. sp.; benevens enkele ervaringen met sterk alcalische voedingbodems. Antonie van Leeuwenhoek 1, 141-147 (in Dutch).

Wieser, M., Worliczek, H., Kämpfer, P. \& Busse, H.-J. (2005). Bacillus herbersteinensis sp. nov. Int J Syst Evol Microbiol 55, 2119-2123.

Wu, C., Lu, X., Qin, M., Wang, Y. \& Ruan, J. (1989). Analysis of menaquinone compound in microbial cells by HPLC. Microbiology [English translation of Microbiology (Beijing)] 16, 176-178.

Wynter, C., Patel, B. K., Bain, P., de Jersey, J., Hamilton, S. \& Inkerman, P. A. (1996). A novel thermostable dextranase from a Thermoanaerobacter species cultured from the geothermal waters of the Great Artesian Basin of Australia. FEMS Microbiol Lett 140, 271276.

Xue, Y., Ventosa, A., Wang, X., Ren, P., Zhou, P. \& Ma, Y. (2008). Bacillus aidingensis sp. nov., a moderately halophilic bacterium isolated from Ai-Ding salt lake in China. Int J Syst Evol Microbiol 58, 2828-2832.

Yamamoto, M., Tanaka, Y. \& Horikoshi, K. (1972). Alkaline amylases of alkalophilic bacteria. Agric Biol Chem 36, 1819-1823.

Yumoto, I., Yamazaki, K., Sawabe, T., Nakano, K., Kawasaki, K., Ezura, Y. \& Shinano, H. (1998). Bacillus horti sp. nov., a new gramnegative alkaliphilic bacillus. Int J Syst Bacteriol 48, 565-571.

Yumoto, I., Yamaga, S., Sogabe, Y., Nodasaka, Y., Matsuyama, H., Nakajima, K. \& Suemori, A. (2003). Bacillus krulwichiae sp. nov., a halotolerant obligate alkaliphile that utilizes benzoate and $m$ hydroxybenzoate. Int J Syst Evol Microbiol 53, 1531-1536.

Zhang, J., Zhang, Y., Xiao, C., Liu, Z. \& Goodfellow, M. (2002). Rhodococcus maanshanensis sp. nov., a novel actinomycete from soil. Int J Syst Evol Microbiol 52, 2121-2126.

Zhang, J., Song, F., Xin, Y.-H., Zhang, J. \& Fang, C. (2009). Microvirga guangxiensis sp. nov., a novel alphaproteobacterium from soil, and emended description of the genus Microvirga. Int J Syst Evol Microbiol 59, 1997-2001. 